\title{
Prolonged Daily Screen-Time among Saudi Secondary School Students
}

\author{
HASSAN M. AL-MUSA, C.A.B.F.M. \\ The Department of Family \& Community Medicine, King Khalid College of Medicine, Kingdom of Saudi Arabia
}

\begin{abstract}
Background: Media is a powerful educational tool for children and adolescents, but they may have a great negative effect on their health. Prolonged screen-time is a risk for several chronic diseases.
\end{abstract}

Aim of Study: To assess daily screen-time among Saudi secondary school students.

Subjects and Methods: Following a cross-sectional study design in Abha City, a total of 384 secondary school students were included. A self-administered questionnaire was developed by the researcher to assess students' screen-time (i.e., more than two hours per day).

Results: Screen times of about three-fourths of secondary school students were more than two hours. Smartphones were the most frequently used electronic devices $(71.1 \%)$, followed by the watching television $(54.4 \%)$, videogames $(50.8 \%)$, and computers $(39.1 \%)$. Screen times increase significantly during weekends $(p<0.001)$. Screen times were significantly higher among males $(p=0.001)$. Students with higher Grade Point Average (GPA) had significantly more screen times $(p<0.001)$ Moreover, students' prolonged daily screen-time was significantly associated with higher family monthly income $(p=0.03)$

Conclusions: Most secondary school students have prolonged daily screen time. The most frequently used electronic devices are smartphones. Use of electronic devices increases during weekends and entertainment is the most frequent purpose for prolonged screen time. Screen-time is significantly higher among boys, those with high GPA and among students in families with high monthly income.

Recommendations: Health education of adolescents and their parents to raise their awareness regarding health risks associated with prolonged screen-time and how they can positively influence their children by enforcing family rules to limit using electronic devices.

Key Words: Screen-time - Electronic devices - Adolescents.

\section{Introduction}

NOWADAYS, with the rapid growth of the digital environment, children and adolescents grow up watching televisions, and using videogames, smart-

Correspondence to: Dr. Hassan M. Al-Musa, The Department of Family \& Community Medicine, King Khalid College of Medicine, Kingdom of Saudi Arabia phones and computers, tablets, and mobile phones associated with their development [1] . However, despite the fact that media is a powerful educational tool for children and adolescents, they may have a great negative effect on their health. With the associated sedentary activity, prolonged screentime is a risk for several chronic diseases, including obesity, declining levels of fitness, malnutrition, and sleep problems [2].

The American Academy of Pediatrics recommended that consistent limits should be placed on the time spent by children using media, less than two hours daily, and to make sure that media does not take the place of adequate sleep, physical activity or other behaviors essential to health [3]

Therefore, the present study aimed to assess screen-time among Saudi secondary school students in Abha City, Saudi Arabia.

\section{Subjects and Methods}

Following a cross-sectional study design in Abha City, Saudi Arabia. All students registered for the scholastic year 2017-2018 at governmental secondary schools in Abha City constituted the study population. The total number of students registered in governmental secondary schools in Aseer Region is 32351 students (18739 boys and 13612 girls), distributed over 168 schools (98 for boys and 70 for girls).

The minimum sample size for this study has been decided according to Dahiru et al., [4], (with a $50 \%$ assumed proportion of participants with prolonged screen-time and a maximum acceptable error of 0.05 ) to be 384 students.

Data were collected during NovemberDecember 2018. A multistage stratified random sample was applied by selecting schools and students from the Directorate of Education in Abha 
City, Aseer Region. Four governmental general secondary schools were selected by simple random sampling technique (two for boys and two for girls) by drawing the names of schools from the sampling frame. After that, three classes of students were randomly selected from each school using a simple random sampling technique (one class for each scholastic grade). All students in a selected class were invited to participate in the study so as to fulfill the required total sample size.

A self-administered questionnaire was used. The questionnaire was designed by the researcher. The study questionnaire consisted of demographic and personal data of students, estimated number of screen-time hours spent by the student. Face and content validity of the study tool was assessed by three academic professors of Pediatrics, Family Medicine and Community Medicine at King Khalid University. Internal consistency of the study questionnaire was assessed by Cronbach's alpha reliability coefficient, which showed values ranging from 0.7 to 0.8 .

A pilot study was applied on 40 students (20 boys and 20 girls at two secondary schools) to test the study tool's applicability and all necessary modifications were made by the researcher to meet the study objectives. Collected data from the pilot study were not used in the main study.

Prior to data collection, all necessary official approvals were fulfilled, i.e., approval of the Educational Affairs in Aseer Region and the selected study schools' directors.

Participation in the study was based on a written informed consent to be signed by each participant student. The researcher stressed that participant responses should not be shared with colleagues. Anonymity of responses was considered to guarantee honest and more accurate self-reporting. All collected data were kept completely confidential and were not used except for research purposes.

The Statistical Package for Social Sciences (SPSS Version 25) was used for data entry and statistical analysis. $p$-values less than 0.05 were considered as statistically significant.

\section{Results}

Table (1) shows that $72.1 \%$ of students were less than 15 years old, while $27.9 \%$ were 15 years or older. Half of students (50\%) were males. About one fourth of students $(22.4 \%)$ were at their first scholastic grade, while $46.9 \%$ were at their second grade and $30.7 \%$ were at their third grade. The
GPA of $46.9 \%$ of students was above $90 \%, 41.4 \%$ had $80-90 \%$, while $11.7 \%$ had $<80 \%$.

Table (2) shows that $60.7 \%$ of students' fathers and $54.7 \%$ of students' mothers were $40-50$ years old, $18 \%$ of students' fathers and $25.5 \%$ of students' mothers were less than 40 years old, while 21.4 of students' fathers and $19.8 \%$ of students' mothers were more than 50 years old. The majority of parents $(93.2 \%)$ were married, while $3.6 \%$ were divorced and $3.1 \%$ were widowed. Half of students' fathers $(50 \%)$ and $36.7 \%$ of students' mothers were university graduates, while $31.8 \%$ of students' fathers and $47.1 \%$ of students' mothers had high school degrees, $4.7 \%$ of students' fathers and $9.1 \%$ of students' mothers were illiterate, while $13.5 \%$ of students' fathers and $7 \%$ of students' mothers had postgraduate degrees. Most students' fathers (59.9\%) were full-time employed, while $40.1 \%$ were part-time employed. Most students' mothers $(77.1 \%)$ were unemployed. The monthly income of $20.8 \%$ of students' families was less than 5000 SR, 44\% had 5000-9999 SR, 30.5\% had 10,00019999 SR and 4.7 had 20,000 SR or more. Almost half of students' (48.2\%) had 4-6 siblings, $29.2 \%$ had less than 4 siblings, while $22.7 \%$ had more than 6 siblings. The majority of students $(88 \%)$ were living with their parents, while $4.2 \%$ were living with their fathers only and $7.8 \%$ were living with their mothers only.

Table (3) shows that $28.9 \%$ of students use electronic devices for less than 2 hours, $45.1 \%$ of students use electronic devices for 2-4 hours, while $26 \%$ use them for more than 4 hours. The smartphones were the most frequently used electronic devices $(71.1 \%)$, followed by the television $(54.4 \%)$, videogames $(50.8 \%)$, and computers (39.1\%), as shown in Fig. (1).

Table (4) and Fig. (2) show that use of electronic devices increases significantly at weekends ( $p$ $<0.001)$. Entertainment was the main purpose for use of electronic devices more than 2 hours daily, followed by watching TV and lastly educational purposes. Use of electronic devices for entertainment and watching TV were significantly more during weekends than weekdays $(p<0.001$ and $p=0.02$, respectively). However, use of electronic devices for educational purposes did not differ significantly during weekends.

Table (5) shows that use of electronic devices for more than two hours was significantly higher among male students than female students $(p=$ 0.001 ). Moreover, there was a significantly higher tendency for longer use of electronic devices among 
students with higher GPA $(p<0.001)$. However, use of electronic devices did not differ significantly according to students' age groups, or scholastic grade.

Table (6) shows that students' prolonged screentime was significantly associated with higher household monthly income $(p=0.03)$. However, their screen-time did not differ significantly according to their other family characteristics.

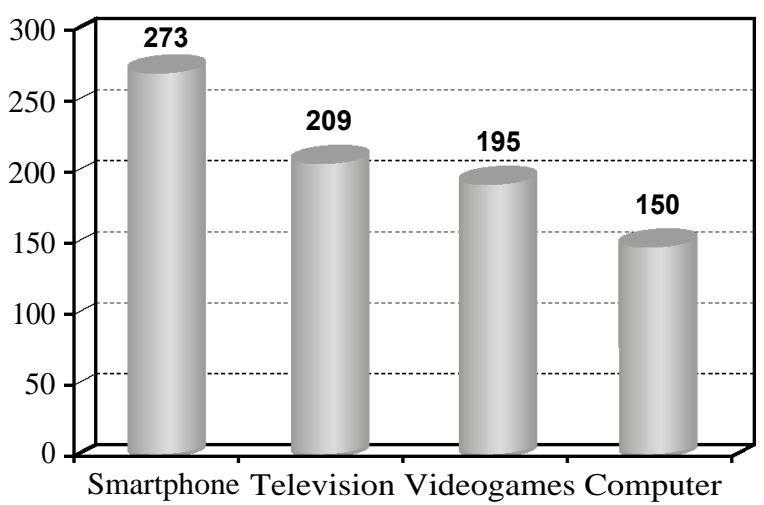

Fig. (1): Used electronic devices.

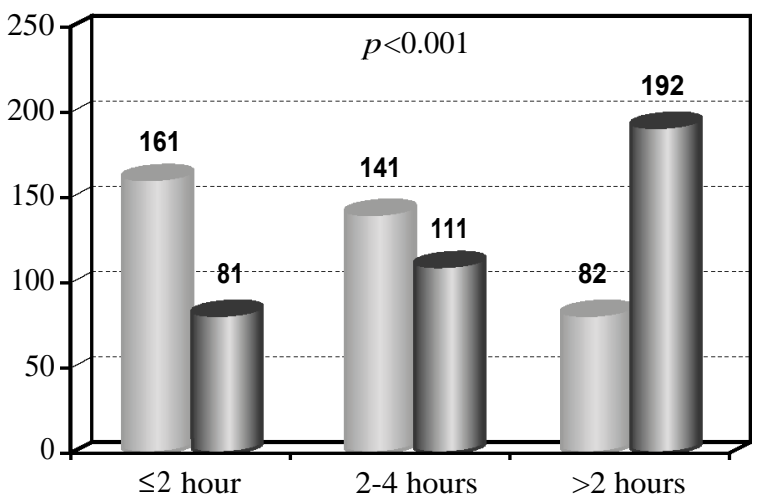

Weekdays Weekends

Fig. (2): Students' daily use of electronic devices during weekdays and weekends.

Table (1): Personal characteristics of participant students.

\begin{tabular}{lcc}
\hline Characteristics & No. & $\%$ \\
\hline Age groups: & & \\
$\quad<15$ years & 277 & 72.1 \\
$\quad>15$ years & 107 & 27.9 \\
$\quad$ Gender: & & \\
$\quad$ Male & 192 & 50.0 \\
$\quad$ Female & 192 & 50.0 \\
Scholastic grade: & & \\
$\quad$ 2nt & 86 & 22.4 \\
3rd & 180 & 46.9 \\
& 118 & 30.7 \\
Previous year's Grade Point Average (GPA): & & \\
$\quad>90 \%$ & 180 & 46.9 \\
80-90\% & 159 & 41.4 \\
$\quad<80 \%$ & 45 & 11.7 \\
\hline
\end{tabular}

Table (2): Personal characteristics of students' family.

\begin{tabular}{|c|c|c|}
\hline Characteristics & No. & $\%$ \\
\hline \multicolumn{3}{|c|}{ Fathers' age groups (in years): } \\
\hline$<40$ & 69 & 18.0 \\
\hline $40-50$ & 233 & 60.7 \\
\hline$>50$ & 82 & 21.4 \\
\hline \multicolumn{3}{|c|}{ Fathers' age groups (in years): } \\
\hline$<40$ & 98 & 25.5 \\
\hline $40-50$ & 210 & 54.7 \\
\hline$>50$ & 76 & 19.8 \\
\hline \multicolumn{3}{|c|}{ Parents' current marital status: } \\
\hline Married & 358 & 93.2 \\
\hline Divorced & 14 & 3.6 \\
\hline Widowed & 12 & 3.1 \\
\hline \multicolumn{3}{|c|}{ Fathers' educational level: } \\
\hline Illiterate & 18 & 4.7 \\
\hline School & 122 & 31.8 \\
\hline University degree & 192 & 50.0 \\
\hline Postgraduate degree & 52 & 13.5 \\
\hline \multicolumn{3}{|c|}{ Mothers' educational level: } \\
\hline Illiterate & 35 & 9.1 \\
\hline School & 181 & 47.1 \\
\hline University degree & 141 & 36.7 \\
\hline Postgraduate degree & 27 & 7.0 \\
\hline \multicolumn{3}{|c|}{ Father's employment status: } \\
\hline Full-time & 230 & 59.9 \\
\hline Part-time & 154 & 40.1 \\
\hline \multicolumn{3}{|c|}{ Mother's employment status: } \\
\hline Employed & 88 & 22.9 \\
\hline Housewife & 296 & 77.1 \\
\hline \multicolumn{3}{|c|}{ Household income (in SR): } \\
\hline$<5000$ & 80 & 20.8 \\
\hline $5000-9999$ & 169 & 44.0 \\
\hline 10,000-19999 & 117 & 30.5 \\
\hline$>20,000$ & 18 & 4.7 \\
\hline \multicolumn{3}{|l|}{ No. of siblings: } \\
\hline$<4$ & 112 & 29.2 \\
\hline $4-6$ & 185 & 48.2 \\
\hline$>6$ & 87 & 22.7 \\
\hline \multicolumn{3}{|l|}{ Child living with: } \\
\hline Father only & 16 & 4.2 \\
\hline Mother only & 30 & 7.8 \\
\hline Both parents & 338 & 88.0 \\
\hline
\end{tabular}

Table (3): Characteristics of using electronic devices (screen time) by participant students.

\begin{tabular}{lcc}
\hline Characteristics & No. & $\%$ \\
\hline Average duration of daily screen time: & & \\
$\quad$ <2 hours & 111 & 28.9 \\
2-4 hours & 173 & 45.1 \\
>4 hours & 100 & 26.0 \\
& & \\
Daily used electronic devices: & & \\
Smartphone & 273 & 71.1 \\
Television & 209 & 54.4 \\
Videogames & 195 & 50.8 \\
Computer & 150 & 39.1 \\
\hline
\end{tabular}


Table (4): Frequency of students' different electronic devices activities during weekdays and weekends.

\begin{tabular}{llllllll}
\hline $\begin{array}{l}\text { Purposes for } \\
\text { screen time }\end{array}$ & $<2$ hours & $2-4$ hours & $>4$ hours & $\begin{array}{c}p \text { - } \\
\text { value }\end{array}$ \\
\cline { 2 - 6 } & No. & $\%$ & No. & $\%$ & No. & $\%$ & \\
\hline $\begin{array}{l}\text { Use of electronic devices: } \\
\quad \text { Weekdays }\end{array}$ & 1 & 41 & 1 & 36.7 & 82 & 21.4 & \\
$\quad$ Weekends & & 21 & 1 & 28.9 & 192 & 50.0 & $<0.001$ \\
Entertainment purposes: & & & & & & & \\
$\quad$ Weekdays & 1 & 45 & 1 & 39.6 & 57 & 14.8 & \\
$\quad$ Weekends & 1 & 30 & 1 & 29.9 & 153 & 39.8 & $<0.001$ \\
Educational purposes: & & & & & & & \\
$\quad$ Weekdays & 2 & 75 & & 20.8 & 14 & 3.6 & \\
$\quad$ Weekends & 2 & 77 & & 17.2 & 19 & 4.9 & 0.327 \\
Watching TV: & & & & & & & \\
$\quad$ Weekdays & 2 & 71 & & 23.4 & 20 & 5.2 & \\
$\quad$ Weekends & 2 & 67 & & 21.9 & 41 & 10.7 & 0.020 \\
\hline
\end{tabular}

Table (5): Duration of students' screen-time according to their personal characteristics.

\begin{tabular}{|c|c|c|c|c|c|c|c|}
\hline \multirow{2}{*}{$\begin{array}{l}\text { Personal } \\
\text { characteristics }\end{array}$} & \multicolumn{6}{|c|}{$<2$ hours $2-4$ hours $>4$ hours } & \multirow{2}{*}{$\begin{array}{c}p- \\
\text { value }\end{array}$} \\
\hline & No. & $\%$ & No. & $\%$ & No. & $\%$ & \\
\hline \multicolumn{8}{|l|}{ Age groups: } \\
\hline$<15$ years & 74 & 26.7 & 126 & 45.5 & 77 & 27.8 & \\
\hline$>15$ years & 37 & 34.6 & 47 & 43.9 & 23 & 21.5 & 0.238 \\
\hline \multicolumn{8}{|l|}{ Gender: } \\
\hline Male & 41 & 21.4 & 103 & 53.6 & 48 & 25.0 & \\
\hline Female & 70 & 36.5 & 70 & 36.5 & 52 & 27.1 & 0.001 \\
\hline \multicolumn{8}{|c|}{ Scholastic Grade: } \\
\hline $1 \mathrm{st}$ & 25 & 29.1 & 40 & 46.5 & 21 & 24.4 & \\
\hline 2nd & 46 & 25.6 & 76 & 42.2 & 58 & 32.2 & \\
\hline $3 r d$ & 40 & 33.9 & 57 & 48.3 & 21 & 17.8 & 0.086 \\
\hline \multicolumn{8}{|c|}{ Grade Point Average (GPA): } \\
\hline$>90 \%$ & 39 & 21.7 & 87 & 48.3 & 54 & 30.0 & \\
\hline $80-90 \%$ & 46 & 28.9 & 72 & 45.3 & 41 & 25.8 & \\
\hline$<80 \%$ & 26 & 57.8 & 14 & 31.1 & 5 & 11.1 & $<0.001$ \\
\hline
\end{tabular}

\section{Discussion}

Findings of the present study revealed that more than half of secondary school students in Abha City use electronic devices for more than two hours, mainly smartphones (71.7\%), TV (54.4\%), videogames $(50.8 \%)$, and computers $(39.1 \%)$.

Similar findings were reported by Patriarca et al., [5] among adolescents aged 11-16 years in the Campania Region, South of Italy, who found that $52.5 \%$ of them always watched television, mostly more than two hours daily and the frequency of watching for at least two hours daily (74.9\%),
Table (6): Duration of students' screen-time according to their family characteristics.

\begin{tabular}{|c|c|c|c|c|c|c|c|}
\hline \multirow{2}{*}{$\begin{array}{l}\text { Family } \\
\text { characteristics }\end{array}$} & \multicolumn{6}{|c|}{$<2$ hours $2-4$ hours $>4$ hours } & \multirow{2}{*}{$\begin{array}{c}p- \\
\text { value }\end{array}$} \\
\hline & No. & $\%$ & No. & $\%$ & No. & $\%$ & \\
\hline \multicolumn{8}{|l|}{ Fathers' age groups: } \\
\hline$<40$ years & 18 & 26.1 & 35 & 50.7 & 16 & 23.2 & \\
\hline $40-50$ years & 68 & 29.2 & 101 & 43.3 & 64 & 27.5 & \\
\hline$>50$ years & 25 & 30.5 & 37 & 45.1 & 20 & 24.4 & 0.845 \\
\hline \multicolumn{8}{|l|}{ Mothers' age groups: } \\
\hline$<40$ years & 24 & 24.5 & 48 & 49.0 & 26 & 26.5 & \\
\hline $40-50$ years & 64 & 30.5 & 92 & 43.8 & 54 & 25.7 & \\
\hline$>50$ years & 23 & 30.3 & 33 & 43.4 & 20 & 26.3 & 0.851 \\
\hline \multicolumn{8}{|l|}{ Current marital status: } \\
\hline Married & 101 & 28.2 & 161 & 45.0 & 96 & 26.8 & \\
\hline Divorced & 4 & 28.6 & 6 & 42.9 & 4 & 28.6 & \\
\hline Widowed & 6 & 50.0 & 6 & 50.0 & 0 & 0.0 & 0.265 \\
\hline \multicolumn{8}{|c|}{ Fathers' educational level: } \\
\hline Illiterate & 8 & 44.4 & 8 & 44.4 & 2 & 11.1 & \\
\hline School & 42 & 34.4 & 51 & 41.8 & 29 & 23.8 & \\
\hline University graduate & 45 & 23.4 & 94 & 49.0 & 53 & 27.6 & \\
\hline Postgraduate degree & 16 & 30.8 & 20 & 38.5 & 16 & 30.8 & 0.192 \\
\hline \multicolumn{8}{|c|}{ Mothers' educational level: } \\
\hline Illiterate & 14 & 40.0 & 17 & 48.6 & 4 & 11.4 & \\
\hline School & 58 & 32.0 & 71 & 39.2 & 52 & 28.7 & \\
\hline University graduate & 33 & 23.4 & 71 & 50.4 & 37 & 26.2 & \\
\hline Postgraduate degree & 6 & 22.2 & 14 & 51.9 & 7 & 25.9 & 0.125 \\
\hline \multicolumn{8}{|c|}{ Father's employment status: } \\
\hline Full-time & 65 & 28.3 & 112 & 48.7 & 53 & 23.0 & \\
\hline Part-time & 46 & 29.9 & 61 & 39.6 & 47 & 30.5 & 0.153 \\
\hline \multicolumn{8}{|c|}{ Mother's employment status: } \\
\hline Employed & 29 & 33.0 & 36 & 40.9 & 23 & 26.1 & \\
\hline Housewife & 82 & 27.7 & 137 & 46.3 & 77 & 26.0 & 0.582 \\
\hline \multicolumn{8}{|l|}{ Household income: } \\
\hline$<5000 \mathrm{SR}$ & 29 & 36.3 & 34 & 42.5 & 17 & 21.3 & \\
\hline 5000-9999 SR & 53 & 31.4 & 79 & 46.7 & 37 & 21.9 & \\
\hline 10,000-19999 SR & 27 & 23.1 & 48 & 41.0 & 42 & 35.9 & \\
\hline$>20,000 \mathrm{SR}$ & 2 & 11.1 & 12 & 66.7 & 4 & 22.2 & 0.030 \\
\hline \multicolumn{8}{|l|}{ No. of siblings: } \\
\hline$<4$ & 26 & 23.2 & 60 & 53.6 & 26 & 23.2 & \\
\hline $4-6$ & 54 & 29.2 & 77 & 41.6 & 54 & 29.2 & \\
\hline$>6$ & 31 & 35.6 & 36 & 41.4 & 20 & 23.0 & 0.163 \\
\hline \multicolumn{8}{|l|}{ Child living with: } \\
\hline Father only & 7 & 43.8 & 5 & 31.3 & 4 & 25.0 & \\
\hline Mother only & 10 & 33.3 & 15 & 50.0 & 5 & 16.7 & \\
\hline Both parents & 94 & 27.8 & 153 & 45.3 & 91 & 26.9 & 0.474 \\
\hline
\end{tabular}

while two-thirds of the students played videogames for 1.6 hours daily and the computer was used by $85 \%$ of the sample for 1.6 hours daily.

In China, Jiang et al., [6] found that TV watching and playing on the computer were the most prevalent screen-time behaviors among adolescents. Playing with mobile phones was less prevalent. In USA, average time spent daily by adolescents in viewing TV was 3.1 hours, while those of videogames playing and computer using were 1.49 and 1.19 hours, respectively [7]. Moreover, in New Zealand, the average time spent daily by adolescents in viewing TV was 3.1 hours [8]. 
Results of this study showed that screen times increase during their weekends and entertainment was the most frequent purpose for using electronic devices. Students' screen times were significantly more among male than female students, and among students with high Grade Point Average (GPA). However, their screen times did not differ significantly according to other personal characteristics (e.g., age group, or scholastic grade). Moreover, screen-time was significantly more among students with higher household monthly income. However, their screen times did not differ significantly according to other family characteristics (e.g., parents' age group, current marital status, educational level, employment status, or number of siblings).

Our findings are in accordance with those of LeBlanc et al., [9], who noted that boys reported significantly more video game/computer usage than girls. Bucksch et al., [10] also found that boys have more screen-time than girls and that there is more ST on weekends than on weekdays. Similarly, Ye et al., [11] reported that male sex, and weekends were significantly associated with prolonged screen time.

Hoyos Cillero and Jago [12] attributed the sex difference regarding screen-time to the observation that boys usually spend more time on computers and tablets than girls. Moreover, Babey et al., [13] reported that boys usually spend more time watching television than girls. Higher household income is associated with more TV watching, but with less computer use.

The lack of significant differences in the present study among students' screen-time according to their age may be explained by the relatively narrow age range, while the significantly more screentime during weekends may be explained by the time spent at school during the weekdays, which is totally spared for free activities, including use of electronic devices, during weekends.

Jago et al., [14] suggested reducing TV-watching time through school-based educational components assisted by parental involvement with students' homework. Jiang et al., [6] added that health education should include adolescents' parents to raise their awareness regarding health risks associated with high screen-time and how they can positively influence their children by enforcing family rules to limit using electronic devices.

The significantly more screen-time among participant students in the present study with higher Grade Point Average (GPA) may reflect the educational benefits of electronic devices. However,
Jiang et al., [6] emphasized the potential harms of excessive use of computers or tablet devices, even when it is for educational purposes.

Results of the present study can be useful for developing and planning effective future preventive strategies against to minimize screen-time among adolescents.

Based on findings of the present study, it can be concluded that most secondary school students in Abha City, have prolonged daily screen times (above two hours). The most frequently used electronic devices are mainly smartphones, TV, videogames, and computers. Use of electronic devices increases during weekends and entertainment is the most frequent purpose for prolonged use electronic devices. Screen-time is significantly higher among boys, those with high GPA and among students in families with high monthly income.

Therefore, immediate and comprehensive actions are needed in order to diminish time spent at watching television, playing videogames, and using computers by adolescents. TV-watching time can be minimized through school-based educational components assisted by parental involvement with students' homework. Moreover, it is necessary to provide health education of adolescents and their parents aiming to raise their awareness regarding health risks associated with high screen time and how they can positively influence their children by enforcing family rules to limit using electronic devices.

\section{References}

1- ASHTON J.J. and BEATTIE R.M.: Screen time in children and adolescents: Is there evidence to guide parents and policy? The Lancet: Child and Adolescent Health, 3 (5): 292-4, 2019.

2- STRASBURGER V.C., JORDAN A.B. and DONNERSTEIN E.: Health effects of media on children and adolescents. Pediatrics [Internet]. Apr. [cited 2016 Dec. 21]; 125 (4): 756-67. Available from: http://www.ncbi.nlm. . nih.gov/pubmed/20194281, 2010.

3- American Academy of Pediatrics Announces New Recommendations for Children's Media Use [Internet]. [Cited 2016 Dec. 24]. Available from: https://www.aap.org/enus/about-the-aap/aap-press-room/Pages/AmericanAcademy-of-Pediatrics-Announces-NewRecommendations-for-Childrens-Media-Use.aspx, 2016.

4- DAHIRU T., ALIYU A. and KENE T.S.: Statistics in Medical Research: Misuse of Sampling and Sample Size Determination. Annals of African Medicine, 5 (3): 15861, 2006.

5- PATRIARCA A., Di GIUSEPPE G., ALBANO L., MARINELLI P. and ANGELILLO I.F.: Use of television, videogames, and computer among children and adolescents in Italy. BMC Public Health, 9: 139, 2009. 
6- JIANG X., HARDY L.L., DING D., BAUR L.A. and SHI H.: Recreational Screen-Time Among Chinese Adolescents: A Cross-Sectional Study. J. Epidemiol., 24 (5): 397-403, 2014.

7- JORDAN A.B., HERSEY J.C., McDIVITT J.A. and HEITZLER C.D.: Reducing children's television-viewing time: A qualitative study of parents and their children. Pediatrics, 118: e1303-10, 2006.

8- HANCOX R.J., MILNE B.J. and POULTON R.: Association of television viewing during childhood with poor educational achievement. Arch. Pediatr. Adolesc. Med., 159: 614-8, 2005.

9- LeBLANC A.G., BROYLES S.T., CHAPUT J.P., LEDUC G., BOYER C., BORGHESE M.M. and TREMBLAY M.S.: Correlates of objectively measured sedentary time and self-reported screen time in Canadian children. Journal of Behavioral Nutrition and Physical Activity, 12: 38, 2015.

10- BUCKSCH J., SIGMUNDOVA D., HAMRIK Z.,
TROPED P.J., MELKEVIK O., AHLUWALIA N., et al.: International Trends in Adolescent Screen-Time Behaviors From 2002 to 2010. J. Adolesc. Health, 58 (4): 417-25, 2016.

11- YE S., CHEN L., WANG Q. and LI Q.: Correlates of screen time among 8-19-year-old students in China. BMC Public Health, 18: 467, 2018.

12- HOYOS CILLERO I. and JAGO R.: Sociodemographic and home environment predictors of screen viewing among Spanish school children. J. Public Health (Oxf), 33: 392-402, 2011.

13- BABEY S.H., HASTERT T.A. and WOLSTEIN J.: Adolescents sedentary behaviors: Correlates differ for television viewing and computer use. J. Adolesc. Health, 52 (1): 70-6, 2013.

14- JAGO R., STAMATAKIS E., GAMA A., CARVALHAL I.M., NOGUEIRA H., ROSADO V. and PADEZ C.: Parent and Child Screen-Viewing Time and Home Media Environment. Am. J. Prev. Med., 43 (2): 150-8, 2012.

\section{التعرض اليومى المطول لطلاب المدارب الثانوية السعوديين

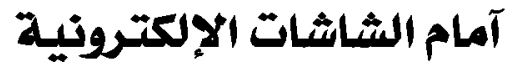

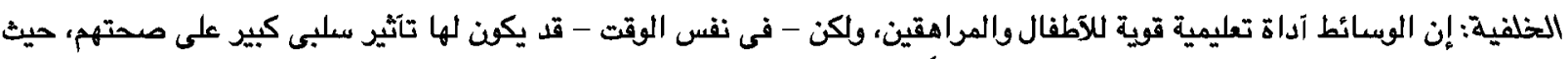

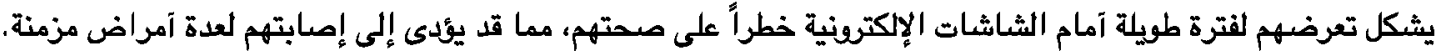 هدف البحث: تقييم وقت التعرض اليومى للطلاب السعوديين بالمدارس الثانوية آمام الشاشات الإلكترونى.

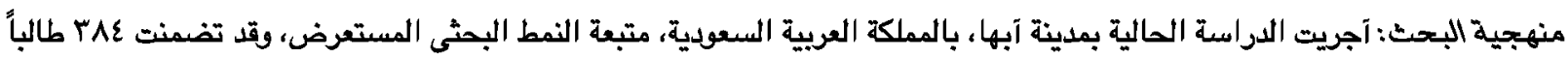

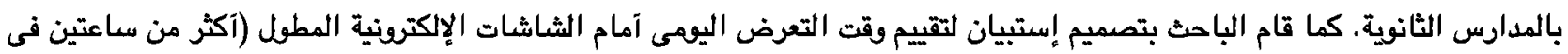
اليوم) للطلاب.

النتائج: كانت آوقات التعرض اليومى آمام الثاشات الإلكترونية لدوالى ثلاثة آرباع طلاب المدارس الثانانية آكثر من ساعتين، وكانت

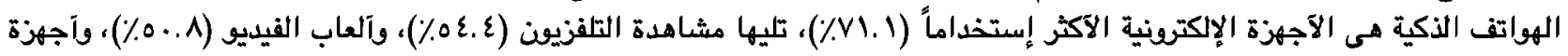

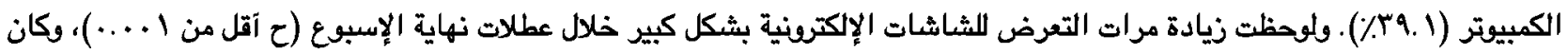

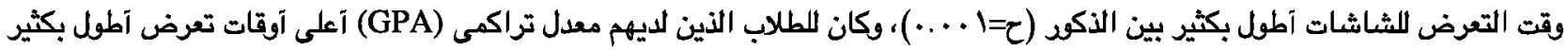

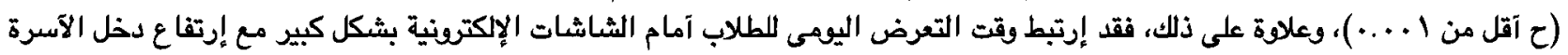
الشهرى (r)

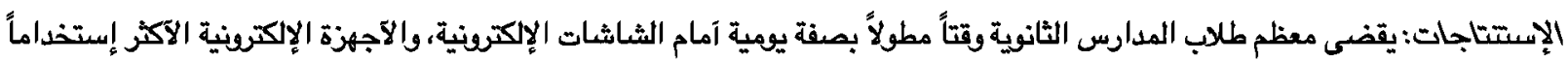

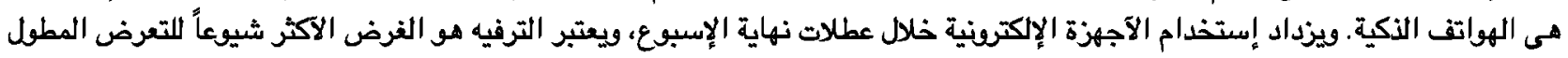

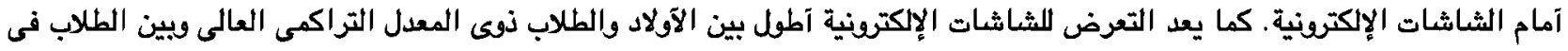
الآسر ذات الدخل الشهرى المرتفع.

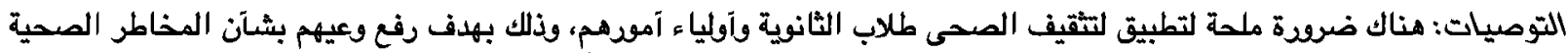
المرتبطة بالتعرض لقترات مطولة آمام الشاشات الإلكترونية، وكيف يمكنهم التآثير إيجابياً على آطفالهم اللحد من الإستخدام اليقيمى المطول 